\title{
Does Local Dairy Agritourism Business Model in Indonesia Concern Animal Health?: Lesson Learned from Cibugary
}

\author{
Annisa Ramadanti \\ School of Business \\ IPB University \\ Bogor, Indonesia \\ aramadanti@apps.ipb.ac.id
}

\author{
Andina Oktariani \\ School of Business \\ $I P B$ University \\ Bogor, Indonesia \\ andina.oktariani@apps.ipb.ac.id
}

\begin{abstract}
Dairy agritourism growth in Indonesia is increasing as it has potentials from its growing demand and business diversification. Many farmers/entrepreneurs work on this potentials to establish a local dairy agro-tourism based on their economic interest. To achieve their economic interest, the dairy agritourism business model should concern animal health, as cows' health will support milk production as well as the main attraction in dairy agritourism. However, there is limited knowledge of cow health in the dairy agritourism business models. This paper aims to describe the business model of Cibubur Garden Dairy (Cibugary) agritourism and examine its concern on animal health. Then, Cibugary agritourism business model is benchmarked to Cimory agritourism business model to compare the level of animal health application. This study found that Cibugary has several areas of improvement to improve the animal health, namely human resources and marketing. Based on the Strengths and Weaknesses (SW) analysis and benchmarking, Cibugary needs to improve its guides' competencies through training, optimize its social media and website to socialize its concern on animal health, and develop more various agritourism packages in the near future.
\end{abstract}

Keywords-animal health, benchmarking, Business Model Canvas, dairy agritourism, $S W$ analysis

\section{INTRODUCTION}

Agritourism represents a touristic offer characterized by an authentic farm holiday experience as it integrates agritouristic services that are closely connected to the farming activities (Eurac Research 2018). In Indonesia, likewise in Malaysia, agritourism could be defined as an activity which maximizes the use of farm settings and the environment, with hospitality in promoting tourism activities (Mansor et al. 2015). Dairy agritourism, as one of agritourism types, offers tourism activities that are connected to the dairy farming and dairy products processing activities. Dairy agritourism in several dairy regions in Indonesia grows in 21 st century, following the potentials from growing demand and business diversification. The potential of growing demand come from various groups, especially students, family, and employees who want to know and experience dairy farming first hand. The potential of business diversification comes from the varied tourism packages (activities) for different customer segments. Dairy agritourism in Indonesia grows in Boyolali, Malang, Bogor, Jakarta,
Karo, Banyumas, and Batu. Many farmers/entrepreneurs work on the potentials to establish dairy agritourism based on their economic interest. Dairy agritourism has potential benefit of generating additional on-farm income and thus contributing to farm resilience (Eurac Research 2018). Agritourism is an important opportunity for farmers to increase their viability and may bolster the profitability of the farms (Barbieri and Tew 2016; Schilling et al. 2014; Schilling et al. 2012). To achieve the economic benefits of agritourism, dairy agritourism business model, among others, should concern animal health, as cows' health will support milk production as well as the main attraction in dairy agritourism. Cibugary is one of dairy agritourism farms that grow in Indonesia. It is located in Pondok Ranggon, East Jakarta, Indonesia. This study is focused on describing the business model of Cibugary agritourism and examining the concern on animal health in the business model. Moreover, Cibugary agritourism business model is then benchmarked to Cimory agritourism business model to compare the business model and the level of animal health application.

\section{MATERIAL AND METHODS}

This study makes use of qualitative method, as well as primary and secondary data. Primary data collected through face to face interview and direct farm observation are used in this study to describe Cibugary agritourism business model and examine its concern on animal health. Secondary data and information obtained from social media are utilized for benchmarking purpose. The study location was selected purposively in Cibugary agritourism farm in Pondok Ranggon, Cipayung, East Jakarta. Cibugary agritourism was selected as it is a local dairy agritourism farm that has survived and been growing for 23 years. The analytical methods harnessed are Business Model Canvas (BMC), Strengths and Weaknesses (SW) analysis, and benchmarking. BMC is used to describe the business model of Cibugary agritourism, SW analysis (on the BMC) is used to examine the business model's concern on animal health, and benchmarking is used to compare the business model and the level of animal health application. The use of BMC and SWOT analysis on the BMC is based on the concept developed by Osterwalder and Pigneur (2010). However, this study only covers 
strentghs and weaknesses as they are the visible ones concerning animal health. BMC had been used to describe many kinds of business model, including agritourism business model (Pölling et al. 2017; Poláková et al. 2015). $\mathrm{BMC}$ is applied widely by scholars and practitioners due to its holistic approach and flexibility (Sahebalzamani and Bartella 2018).

BMC consists of nine building blocks, usually drawn on one page, which describe how an organization creates, delivers, and captures values. BMC and its elements can be evaluated using SW analysis (Osterwalder and Pigneur 2010). In this context, the BMC elements evaluated are the ones associated with concern on animal health. Thus, the business model's concern on animal health can be examined. Benchmarking method is conducted after the business model of Cibugary is described and examined. Benchmarking method was used for tourism study by Andermo (2014).

\section{RESULT AND DISCUSSION}

\section{A. The Business Model of Cibugary Agritourism}

The business model of Cibugary agritourism is depicted in Fig. 1, with agritourism as its main value proposition. Cibugary was a family-owned dairy farm and bequeathed to the current owner as the son of the privious owner. At the beginning of Cibugary, 1994-1996, the current owner only sold the fresh milk at school canteen and nearby small shop, with the brand of Cisugara and Cibugary. However, he realized that it was an ineffective way of selling the fresh milk. In 1996, the brand of Cibugary was patented. An opportunity for agritourism arose when there were people, initially school friends and general public, who wanted to visit his dairy farm, looking at how the fresh milk is produced. Since then, Cibugary started developing its agritourism business model.

In addition to its agritourism activities, Cibugary also produces various dairy products, which also become parts of agritourism activities (souvenir giving). The dairy products produced by Cibugary are fresh milk, pasteurized milk with various flavours, yogurt (bottled and stick), and mozarella cheese.

Most of the customers of Cibugary agritourism (50\%) are kindergarten and elementary school students. The remaining $50 \%$ comprises groups of family, employees, and retired employees. The agritourism activities offered for the first and second half of customer segments are quite different. The agritourism activities for students are education about fresh milk (taste, processing, and benefits) including drinking the milk, theoretical education about the dairy cows (feeds, drink, and care/management), technical experiences concerning dairy cow (cleaning, milking, and feeding the cow), and souvenir giving (dairy products of Cibugary). Agritourism activities for family are simplified with milking the cow as the main attraction (charged with slightly higher price than the package with no milking experience). Meanwhile, agritourism activities for employees and retired employees focus on the training on making dairy products or entrepreneurship training, certainly with different price. The agritourism activities, other than training, usually take place for 3 to 4 hours. The lowest price (per visitor) of agritourism package is offered for family group as the package is the simplified one. The price for the other agritourism package, other than training, ranges between $\mathrm{Rp} 50.000$ and $\mathrm{Rp} 100.000$ per visitor. Cibugary has remarkably accepted a thousand visitors per year. In fact, Cibugary also accepts various visit from foreign tourists/institutions, but it is unknown whether Cibugary obtained revenues from such visit, except the tourists buy the dairy products of Cibugary.

\begin{tabular}{|c|c|c|c|c|}
\hline $\begin{array}{l}\begin{array}{l}\text { Key } \\
\text { Partners }\end{array} \\
\begin{array}{l}\text { Suppliers } \\
\text { of feeds }\end{array} \\
\begin{array}{l}\text { Supplier of } \\
\text { dairy } \\
\text { farming } \\
\text { tools }\end{array} \\
\text { Office of } \\
\begin{array}{l}\text { Agricul- } \\
\text { ture of } \\
\text { Jakarta }\end{array}\end{array}$ & 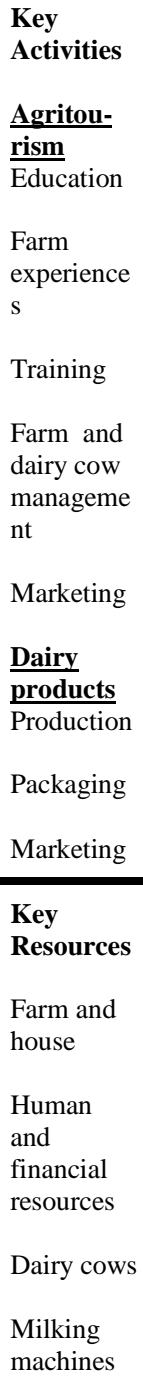 & $\begin{array}{l}\text { Value } \\
\text { Proposi- } \\
\text { tions }\end{array}$ & $\begin{array}{l}\text { Channels } \\
\text { Farm } \\
\text { Website, } \\
\text { social media, } \\
\text { WA, and } \\
\text { mass media } \\
\text { Market-place } \\
\text { Word of } \\
\text { mouth }\end{array}$ & $\begin{array}{l}\begin{array}{l}\text { Customer } \\
\text { Segments }\end{array} \\
\frac{\text { Agritou- }}{\text { rism }} \\
\text { Students } \\
\text { Family } \\
\text { Employees } \\
\begin{array}{l}\text { Retired } \\
\text { employees }\end{array} \\
\frac{\text { Dairy }}{\text { products }} \\
\begin{array}{l}\text { General } \\
\text { community }\end{array} \\
\begin{array}{l}\text { Restaurants } \\
\text { /shops }\end{array}\end{array}$ \\
\hline \multicolumn{3}{|c|}{$\begin{array}{l}\text { Cost Structure } \\
\text { Agritourism } \\
\text { Dairy products }\end{array}$} & \multicolumn{2}{|l|}{$\begin{array}{l}\text { Revenue Streams } \\
\text { Agritourism } \\
\text { Dairy products }\end{array}$} \\
\hline
\end{tabular}

Fig. 1. The business model of Cibugary agritourism

Other than being provided to the agritourism visitors as souvenirs, the dairy products of Cibugary are also sold for profit. They are sold to the general public (by order especially for bottled yogurt, mozarella cheese, and pasteurized milk) and to restaurants and shops. 
The agritourism activities are fully conducted on farm. They are introduced and marketed through the website (www.cibugary.com or www.cibugary.co.id), social media (Instagram, Facebook, and Youtube), and mass media (local TV shows and news coverage). The most active marketing channel for Cibugary agritourism is Instagram. Through local TV shows coverage, Cibugary agritourism farm had been visited by many local artists. In terms of dairy products, Cibugary markets its dairy product through word of mouth and marketplace (Tokopedia).

Customer relationships currently carried out by Cibugary are only limited on marketplace through review of its dairy products from the customers/consumers, and communication-and-consultation with training participants through WhatsApp (WA) group. WA group facilitates the training participants to easily ask Cibugary about the practical things they learn on the training, especially when they face some problems practicing at home.

Through the series of value propositions, customer segments, channels, and customer relationships, Cibugary obtains revenues through its agritourism packages and dairy products selling. However, its main revenue stream is from agritourism activities.

Beside performing common agritourism services mentioned above (education, farm experiences/tour, and training), Cibugary also conducts daily farm and dairy cow management, as well as marketing activities to support the agritourism activities. For dairy products, Cibugary conducts daily production and packaging of dairy products, as well as ocassional marketing activities.

To conduct its activities, Cibugary certainly needs some essential resources, namely farm and house, human resources, financial resources, dairy cows, and milking machines. Farm is used for fresh milk production and agritouris, house is used for dairy products production, human resources employed are the owner, a farm manager, a financial manager, a vet, an outsourced artificial insemination officer (from the local government), and agritourism guides, dairy cows are the fresh milk producers and the main attractions of the agritourism, and milking machines are the latest technologyadopted by Cibugary.

Cibugary partners with suppliers of concentrate feeds and dairy farming tools. Besides, Cibugary works together with the Office of Marine, Agriculture, and Food Security of Jakarta (DKPKP) concerning animal husbandry programs and agritourism development program.

Through the series of key activities, key resources, and key partnerships, Cibugary incurs the cost of operation, farm and dairy cow management, human resources, and marketing for its agritourism activities and the cost of production, packaging, and marketing for its dairy products production. For agritourism, the cost of farm and dairy cow management holds the highest proportion.

\section{B. Cibugary's Concern on Animal Health}

Cibugary's concern on animal health is portrayed in Fig. 2, reflected through the strengths (S) and weaknesses (W) it has concerning animal health. Cibugary's main strength concerning animal health is the employment of a knowledgable farm manager. The farm manager employed there, still a family to the owner, is a graduates from animal usbandry bachelor program of IPB University. He is in charge of farm management and dairy cow management (animal health care). He learned the technical practices of animal health (other than artificial insemination and the vet's tasks) from the previous paramedics. He has worked at Cibugary since 2006. Besides, the strength also exists on the vet's daily visit to check the cows. The concept of agritourism itself (education and pratical experiences) becomes a strength concerning animal health for Cibugary. Before educating and showing the visitors about its milk and cows, Cibugary must concern on the cows' health first to convince the visitors that the milk it produces is from a relatively safe and healthy process. The use of milking machines starting 2016 also becomes Cibugary's strength as it makes the milking process cleaner and healthier for the cows (associated with udder cleanliness and health).

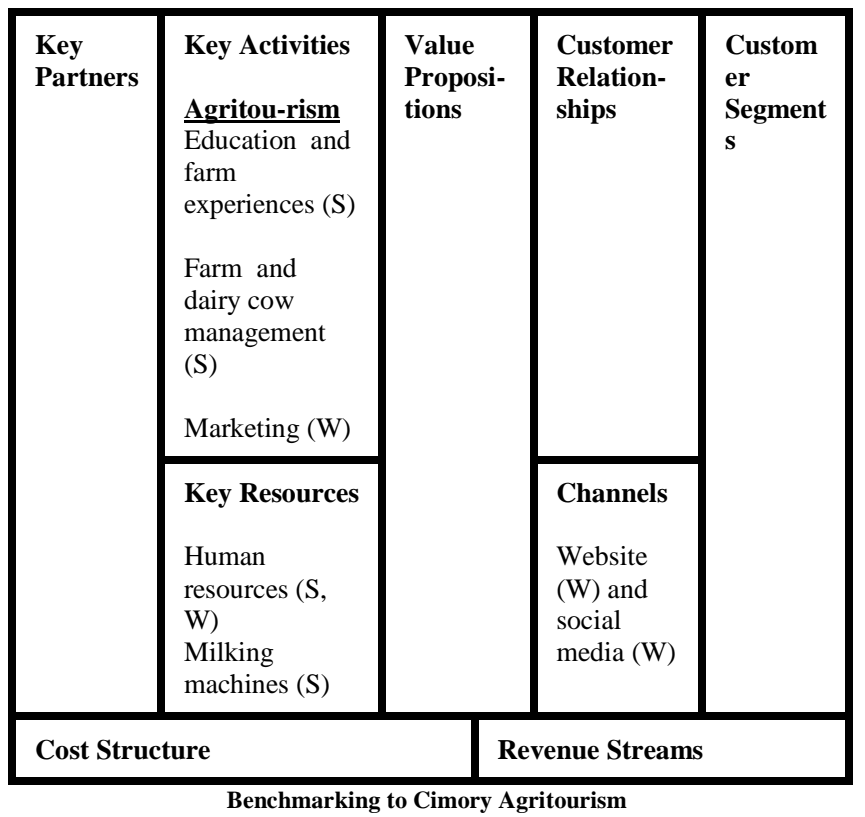

Fig. 2. Cibugary's concern on animal health

Cibugary still has weaknesses concerning animal health mainly in terms of human resources, specifically the lack of competent agritourism guides. Currently, Cibugary has five agritourism guides, but only two of them who are really competent on educating and guiding activities. The guides are the ones who will explain to the visitor how Cibugary pays attention to the cows' health. Besides, Cibugary has weaknesses concerning animal health in terms of marketing. Cibugary can utilize its social media and website to socialize and convince the public about Cibugary's concern on animal health. 
Cimory is a large-scale milk processing company that is leading in the implementation of dairy agritourism concept in Indonesia. Thus, Cimory becomes the benchmark for Cibugary in terms of the business model in general and the animal health in particular. Cimory has three dairy agritourism locations, namely Cimory Dairy Tour in Puncak-Bogor, Cimory on the Valley in Bergas-Semarang, and Cimory Dairy Land in Prige-Pasuruan. Cimory conducts its dairy tour/experiences (cow story, cow milking, and cow feeding) in its mini farm. Cimory explains and convince its visitors that it uses only good quality cows and performs high maintenance and quality control on them. Besides, to familiarize the cows to the visitors, especially the kids, Cimory gives name to each cow and calf milked and introduced to the visitors, called Cimo and Mory. Moreover, Cimory also provides dairy educational movie which highly attracts the kids. Through this movie format, Cimory has an efficient way to show its high concern on animal health. Other vital aspect concerning animal health is that Cimory certainly hires professional staffs for animal health care, other than the vet.

Meanwhile, in terms of the agritourism business model in general, Cimory provides more various tourism activities/services to accompany its dairy agritourism activities, such as go to Cimory Riverside (restaurant and environmental tourism object), welcome drink, visit monster aquarium, visit Chocomory shop, visit Cimory dairy shop, lunch, milkshake demo, and goody bag.

\section{CONCLUSION}

The business model of Cibugary has agritourism as its main value proposition and it is interconnected to the production of its dairy products. It's concern on animal health is visible through its knowledgable farm manager and the agritourism concept itself. However, it still has rooms for improvement concerning animal health in human resources (agritourism guides) and marketing. Along with Cibugary's growth in the future, it is also expected to improve its animal health care practices. Learning from Cimory agritourism concept, in terms of business model in general, Cibugary can expand its agritourism packages to attract its segments better. In terms of animal health in particular, Cibugary can enhance its farm manager competencies through trainings, sharing from professionals, or even further education, while preparing for its successor/replacement.

\section{REFERENCES}

[1] Andermo A. 2014. Revealing Georgia's tourism potential [thesis]. Södertön University, Stockholm.

[2] Barbieri C and Tew C. 2016. Perceived impact of agritourism on farm economic standing, sales, and profits. Travel and Tourism Research Association: Advancing Tourism Research Globally. 34

[3] Eurac Research. 2018. Outcome statement 1st world congress on agritourism. Available online: http://agritourism.eurac.edu (accessed on 14 October 2019).

[4] Mansor N., K.M. Rashid, Z. Mohamad, and Z. Abdullah. 2015. Agro tourism potential in Malaysia. IARJ-BT. 1(2), pp. 37-44.

[5] Osterwalder A. and Y. Pigneur. 2010. Business model generation. John Wiley \& Sons, New Jersey.

[6] Poláková J., G. Koláčková, I. Tichá. 2015. Business model for Czech agribusiness. SAB. 46(3), pp. 128-136.

[7] Pölling, B., M. Prados, B.M. Torquati, G. Giacché, X. Recasens, C. Paffarini, O. Alfranca, and W. Lorleberg. 2017. MGR. 25(3), pp. 166-180.

[8] Sahebalzamani S. And G. Bartella. 2018. Business models and sustainability in nature tourism: a systemic review of the literature. Sustainability. 10(3226), pp. 1-15.

[9] Schilling, B.J., K.P. Sullivan, and S.J. Komar. 2012. Examining the economic benefits of agritourism: the case of New Jersey. JAFSCD. 3(1), pp. 199-214.

[10] Schilling B.J., W. Attavanich, and J. Yanhong. 2014. Does agritourism enhance farm profitability? JARE. 39(1), pp. 69-87. 